\title{
An East-West Divide in the European Union? The Visegrad Four States in Search of the Historical Self in National Discourses on European Integration
}

\author{
CHRISTOPHER WALSCH
}

$\frac{\text { DE }}{\mathrm{G}} \stackrel{\text { DE GRUYTER }}{\text { OPEN }}$

Politics in Central Europe (ISSN: 1801-3422)

Vol. 14, No. 2

DOI: $10.2478 /$ pce-2018-0015

\begin{abstract}
This article explores whether a new east-west divide exists in the enlarged European Union by analysing national discourses on European integration in the Visegrad Four (V4) states. Two V4 foreign policy legacies form the basis of analysis: the "Return to Europe" discourse and the discourses around the reconstruction of the historical self. The article gives evidence that the V4 countries share sovereignty in external policies and thus have a distinct European orientation. V4 national-conservative governments hold sovereigntist positions, however, in policy areas that they consider falling exclusively within the realm of the member state. Comparison with Western European member states gives evidence that the post-1945 paradigm changes were more profound than those of post-1989 ones of Eastern Europe. This historic legacy can explain the more integrationist orientations in Western Europe. The article concludes that behaviour of the individual V4 state seems to be of greater importance for each member than collective V4 group action. Finally, the article gives an outlook on ways in which solidarity between the Western and Eastern halves of the EU can be exercised in an ideologically diverging Union.
\end{abstract}

Keywords: European integration, Eastern Europe, Western Europe, Visegrad Group, constructivism 


\section{Introduction}

The chapter asks whether behind discourses on European integration, which since the 2015 refugee crisis have entailed considerable disagreement between and within EU member states, we can observe a new east-west divide in the enlarged European Union, and whether, because of the importance of the Visegrad Four (V4) group in the EU's eastern half, this regional grouping can be considered to be at the helm of such a divide.

We observe that there is evidence of both similarities and differences between positions that run along a line of formerly old and formerly new member states. We observe also that positions within the putative two blocks differ considerably. Division within a perceived "block" challenges the concept of such a divide and the logical level of examination thus becomes the individual EU member state: wherever situated, big or small, greatly exposed to refugee and migration flows or less so, a Eurozone member or not, a net contributor or a net recipient, a member state subject to many infringement proceedings or few, and subject to the EU rule of law mechanism or not. Furthermore, the member state is an actor that, depending on the policy area, often behaves flexibly and pragmatically in everyday politics. This wide array of potential variables is most likely to present a very mixed outcome and would hardly give evidence of an east-west divide, but could, however, be an interesting starting point for a quantitative analysis based on data sets that can be operationalised.

In this contribution, a qualitative analysis will be provided that draws on some of these variables. The method will apply a social constructivist perspective to the relations between EU member states on the basis of discourse analysis and qualitative comparative analysis. The objective is to identify foreign policy identities, which are guided by norms and ideas, and to analyse foreign policy behaviour, which is addressed to a political other. These discourses between self and other construct and reconstruct identities (Wendt 1999; on discourse and the construction of self and other Diez 2004 and Hansen 2006). Behaviour moves in paths, over time creating a culture and traditions. Historic turning-points

in East Central Europe, with sequences of foreign subjection and self-rule, produced a set of sometimes contradictory traditions, referred to as historical legacies (Wittenberg 2015). Could it be that historical legacies in Western Europe and Eastern Europe differ so greatly that they have the potential to divide the continent, more than twenty-five years after the fall of the iron curtain and nearly fifteen years into EU membership?

\section{East Central Europe: two legacies since 1989}

With the two basic concepts to be laid out below, we follow Elsa Tulmets' book East Central European Foreign Policy Identity in Perspective (Tulmets 2014). Here 
she observes two legacies. The first is the "Return to Europe" line of thought, which emerged in both Eastern and Western Europe. The continued illegitimacy of the socialist one-party states, the role of revolts and the legitimacy of the dissidence movements led to an enthusiastic "Return to Europe" by the new democratically elected governments of East Central European (ECE) states. The new political self embraced the promotion of democracy, human rights, security and a market economy. This led in 1990 and 1991 (and for the peacefully separated Czech Republic and Slovakia again in 1993) to membership in the Council of Europe, in 1999 to NATO (Slovakia in 2004) and in 2004 to the European Union. Full-fledged membership in these three institutions and the OECD signify the culmination of the Visegrad states' "Return to Europe" and the West. The institutions stand for a return to a political order legitimised through democracy and the rule of law, a liberal economic and social order with the belief in prosperity through market economy and modernisation, and a return to a security order through a continued Atlanticist orientation (Tulmets 2014: 60-62). This "Return to Europe" was questioned by a small minority of ultranationalists on the right and an even smaller minority of old school communists on the left. Sovereigntist tendencies were overwhelmingly overridden by integrationists.

The second concept in Elsa Tulmets' book is the definition and reconstruction of the historical self in ECE states. At the time of EU accession, Hungarian political scientist László J. Kiss highlighted this second concept when in 2004, he wrote:

The all too frequently repeated cliché 'return to Europe' means more than advancing towards West European and Atlantic institutions; it also means the return to 'old' neighbourhoods and interrelated problems, i.e. history itself. For $[\ldots]$ the region the regime change comprised the simultaneous re-conquest of their history [...]. (Kiss 2004: 66)

In this concept, the weight of a nation's history is an important factor in the definition of its identity. All of the countries in ECE have experienced a problematic relationship between their sense of state and their sense of nation. In their own ways, all have historically struggled with both self-rule and the dominating influence of foreign powers in the region. Despite a Western, and to a lesser extent regional orientation in all major political camps, the European dividing line ran between a more universalistic liberal approach to formulating identity on behalf of the moderate left and an ethno-cultural approach to formulating identity by the national-conservative right. 


\section{A new experience since 2004: sharing sovereignty in EU policies}

Tulmets' text continues to analyse in detail contributions of ECE states to the EU foreign policies towards the eastern and south-eastern neighbourhoods, namely participation in the Eastern Partnership and EU enlargement policies (Tulmets 2014: 147-184). Since 2004, a "Europeanisation" of the foreign policies of the Visegrad states has taken place in this respect, and the text rightfully labels this as a "turn" (Tulmets 2014: 151) in ECE foreign policy behaviour. A case study of mine on Visegrad Four relations towards Bosnia confirms this integrationist behaviour (Walsch 2015). The new ECE identity of being a successful transformer, and subsequently achieving full membership to the EU, is used to serve as an example in these eastern and south-eastern regions that are being encouraged to develop along the same path. Domestic divisions and diverging political identities in Visegrad countries have, overall, little or no impact in these multilateral formats.

Tulmets also observes a "foreign policy consistency through the presidencies of the Visegrad Group and of the EU Council" (Tulmets: 185-219, citation 185). Such presidencies require a high degree of co-ordination and co-operation with the respective partners. Congruent with many EU member states that had held EU Council presidencies before, V4 states led the European Union with a dual strategy. On the one hand they fulfilled the role of being a 'first among equals' and an 'honest broker.' On the other hand, each ECE country that presided over the EU engaged in the thematic or geographical priorities most in line with its own foreign policy identity. The Hungarian presidency, for example, could successfully finalise the accession negotiations with the then candidate state of Croatia in the first half of 2011.

There is a different picture when it comes to internal European or - to use the term of the respective Council formation - 'General' affairs. National-conservative right wing parties react vehemently at the first perceived threat to national sovereignty, when the self that they have constructed domestically is encroached upon through European politics, as in rule of law issues or asylum policies. When analysing Visegrad Four co-operation in earlier contributions of mine, I distinguished an "internal" from an "external" dimension (Walsch 2014: 30-35). In accordance with Tulmets' findings above, I found overwhelming evidence that co-operation is by and large successful as long as a third party is concerned. Regardless, the Visegrad Four shy away from agendas that may limit each other's sovereignty in a wide array of policy areas of domestic relevance (ibid). V4 partners do not want to touch each other's sovereignty, however they occasionally will in the bilateral format. The short-term domestic gain of non-involvement seems to outscore a potential win-win-situation of deeper co-operation. At the EU level, the behaviour of V4 governments with nationalist and thus sovereigntist inclinations unfold along the same pattern. 
More than twenty-five years after the fall of the iron curtain, and after twelve years of full membership in the most powerful alliance on the continent, it is striking that even with new shared sovereignty for ECE states, EU national-conservative parties have done little or nothing to erase or at least alter the overarching narrative of victimhood at the hands of some bigger outside force. "Brussels" is sold as "not us": the powerful other that regularly interferes in "our" domestic affairs. This narrative of defending the own small nation from the big other has become a consistent theme in the region and fits well into the narrative of the $20^{\text {th }}$ century tragedies of Central Europe, along with such tragedies as the expansion of Nazi Berlin and of communist Moscow. In reality, decision-making has changed completely since 2004. Today Brussels is Budapest, Brussels is Warsaw, etc. Communist Moscow and Nazi Berlin were not. What is self and what is other have changed in the everyday practice of EU governance, but the narrative that a bigger power from outside threatens "us" is cultivated anew and conveniently feeds into a seemingly uninterrupted storyline of victimhood and self-defence.

\section{Paradigm changes: what is different in the west of the EU?}

In searching for differences between former Western and former Eastern Europe, two arguments should be brought forward. The first is that the disasters of fascist rule and World War II functioned in Western Europe as a catharsis and led to profound redefinitions of self and other. This transformation left behind the legacy of aggressive nationalisms. In post-war Europe, six Christian Democrat governments (not national-conservative ones) decided to form the European Communities (Judt 2005). Post-1968, the West German centre-left government initiated a new Ostpolitik of co-operation with communist Europe, a move that was not renounced by subsequent centre-right governments. 198990 was seen as a historic turning point in the advancement of European unity by all major political camps across western European countries. These policies prove that both major political camps could leave behind earlier historic legacies of division and ideological orthodoxy for the sake of new opportunities for co-operation and eventual integration (on Germany see Ash 1993). In Eastern Europe, 1989 cannot be seen as a catharsis. It was simply liberation. The chance to critically reflect on past identities, which had been incorporated into building the present one, was rarely undertaken. Rather recourse to legacies of the pro-communist times, the interwar period, can be observed within the political right. Hungary, for example, under the national-conservative government of Viktor Orbán, cultivated anew the "tragedy" of the Trianon Peace Treaty of 1920, which had been a dominant storyline of Horthy's interwar Hungary. In contrast, post-1949 West German and post-1990 German elites have not initiated a political discourse on the Treaty of Versailles. 
Second, the war legacy gave birth to a profound paradigm shift in continental Western European political culture: from confrontation to consensus-orientation. Even today, after more than seventy - or in the Iberian case forty years of democratic practice, we do not see a fundamental divide over European integration in the catch-all centre-right and centre-left parties. This is a remarkable achievement, and decision-making culture in European institutions reflects this consensus approach. It should be noted that, in the eyes of the socialist and social democratic parties, the European Community was initially a rather suspicious western capitalist undertaking, and still there was willingness from both sides to co-operate. In Eastern Europe, the round-table negotiations of the 1989 revolutions, as well as the peaceful divorce of Slovakia and the Czech Republic, gave proof of elite consensus orientation; likewise, few ECE government coalitions have crossed the sovereigntist-integrationist trench post-1990. The abovementioned practice of sharing sovereignty and contributing to joint decisions based on consensus orientation in EU institutions can also already count as a newly acquired tradition. However, the older socialist legacy of superficial one-party dictated consensus-making and pre-war legacies of confrontation presaged the hard divisions that would arise on European issues between the two camps. Confrontationists - usually Kulturkampf-type politicians - reject proposals that are not their own. This consequently leads to a boycott of joint processes and decisions in domestic politics. On the European level, the failure to reach a compromise is then well exploited by sovereigntists for short-term domestic gains. A well-known strategy to this end is the inventing of an enemy along the scheme of a negative other that helps to reinforce a separated self. Also, it seems that confrontation - or veto-playing - is not helpful at the European level. What does prove effective, however, are the domestic traditions of consensus orientation in continental Western Europe. For example, Scandinavian countries have often experienced minority governments, which rely on compromises with non-government parties in order to reach majorities in parliament (Gallagher - Laver - Mair 2005: 388-391 and 395-397). In many countries, work in parliamentary committees also requires compromise between government and opposition (ibid, 64-66). This legacy of openness proves helpful when it comes to co-shaping issues and finding majorities in various EU Council of Ministers configurations.

\section{In search of solidarity}

Solidarity between Western and Eastern Europe has been relentlessly under attack since the outbreak of the refugee crisis. Quarrels over this issue and V4 unity on it have become, in Zsuszánna Végh's words, a “dubious trademark" of Visegrad Four co-operation (Végh 2017). The laurels of "top democracy transition achievers" (Kořan 2017) can be revoked from Hungary and Poland, 
now borne only by other ECE countries. The laurels should also be returned to Spain, for example, whose functioning democracy has so far been able to deal with a severe and prolonged economic crisis, and to a lesser extent with the challenges of an independence struggle in the autonomous region Catalonia.

French president Macron's warning that the EU is not a "self-service supermarket", along with Commission President Juncker's statement of solidarity being a two-way avenue, casts a dark shadow over today's Kaczyńskis and Orbáns. Then there are also the innumerable criticisms from the centre-left, among them those from acting and former prime ministers of Western European EU countries. Such cumulated criticism tipped off the Visegrad Four prime ministers, and recent V4 statements on the refugee issue have dropped the term "solidarity" like a hot potato (The Visegrad Group 2017). There is also evidence that some hard-line positions were removed from official V4 statements in response to Czech and Slovak pressure (Dostál 2017; Cabada 2018). One could label this divided constellation V2+2. However, whenever disagreement flares among Visegrad partners, it is consequently sold as flexibility. To be sure, V4 is alive in a number of policy areas, but is currently in crisis over the refugee issue, that same issue that united the four countries in 2015, at the time when the different reactions vis-à-vis Russia's aggression against Ukraine held the Four hostage in a previous crisis... (for a good discussion on V4 and Russia and Ukraine see Kucharczyk and Mesežnikov 2015). Considerable V4 disagreement over both the Ukraine and the refugee issues show that consensus among the four partners is limited to the extent that it becomes difficult to recognize a common position.

On a more abstract level, it is important to explore the definitions of solidarity within the EU. At the heart of the EU solidarity debate is the mainstream conviction that one type of solidarity, for example cohesion funding, does not go without the other, in this case burden-sharing in the refugee issue. Focusing just on the issues of the refugee crisis, the mainstream conviction is that solidarity encompasses both an external and an internal dimension. This means that common EU (Schengen) external border protection goes hand in hand with the establishment of a common European asylum policy, the corresponding internal dimension. The governments of the $\mathrm{V} 4$ states nevertheless insist on a separation of the two dimensions and advocate more flexible approaches. V4 supports common policies on border protection and fighting root causes of migration, but ferociously reject any common European approach to asylum and migration policies.

This is seen by Western European countries as a cherry-picking, a-la-carte-type solidarity at the discretion of the single EU member state. Negotiations over the EU-budget 2021-27 will bring this debate to its inevitable climax. The EU budget will shrink due to the exit of the net-contributor Great Britain. More importantly, the wealthy EU states of Western and Northern Europe will be cast 
into a stronger position as the remaining net-contributors to the EU budget. It is possible that these countries will take the opportunity to limit budgets for future EU cohesion funding, due to a perceived lack of solidarity on behalf of the V4 and other ECE states. The southern EU states of Italy, Greece, and Spain, who are all heavily exposed to refugee and migration flows, are not particularly keen to further endow their stubborn Eastern cousins, when rather EU solidarity is needed in tackling this paramount and Europe-wide issue. Despite a rift within the EU between 'North' and 'South' on how to move forward regarding governance of the Euro, southern EU states can presently count on the solidarity of their northern partners. Thus, it is the V4 states that are rather isolated in this matter.

A final important point of the solidarity debate regards European Union Treaty obligations and the "rules-based" order, lying at the heart of the whole European integration framework. It can be illustrated by the impact of the Justice and Home Affairs Council Decision of 22 September 2015, which had prescribed the compulsory distribution of a small number of refugees with granted asylum status from Italy and Greece to all other EU member states (Council of the European Union 2015). The Council Decision did not pass unanimously, but rather with a qualified majority. Hungary, Slovakia, the Czech Republic and Romania voted against it; Finland abstained. (The then pro-European Polish government voted in favour. A new Czech government, in place since December 2017, announced that it would maintain the position of its predecessor.) This compulsory relocation scheme dictated that 1294 refugees be relocated to Hungary, 5082 to Poland, 802 to Slovakia and 1591 to the Czech Republic (ibid). Slovakia and Hungary appealed against the Council Decision at the European Court of Justice, but lost their case. The Court ruled that the decision had been made in accordance with the Treaties of the European Union, and consequently EU member states are obliged to implement the Council Decision (Court of Justice of the European Union 2017). Currently three governments - those of Hungary, Poland and the Czech Republic - further insist on non-implementation. In many European capitals, this continued stubbornness is interpreted as a violation of the rules-based order with which every member must comply. Continued non-compliance can quickly bring into question the sense of the whole edifice of co-operation and solidarity. Seen through the lens of future EU cohesion funding, net-contributors have leverage over those members who violate the rule of law, and can impose much stricter conditions concerning the use of future cohesion budgets. In the worst-case scenario, net-contributors may consider stopping cohesion funding for members that violate the rule of law principle and setting up new schemes for those members and initiatives that comply with common rules and regulations. As the conclusions will demonstrate, the worst-case scenario could even have this happening in bi- and multilateral agreements outside European Union structures. 


\section{Conclusions: any alternatives?}

Despite the advantages and disadvantages of regional co-operation, it is the individual member state that will be appraised by Brussels. Two issues against a number of member states - all of which are situated in the ECE region - are currently at the forefront. First, the rule of law mechanism (which is related, but still different from judgements of the European Court of Justice on specific cases or proceedings) is in force for Poland and Hungary. After years of intensive consultation, the European Commission decided to activate Article 7 of the Treaty of the European Union against Poland in December 2017 due to non-compliance with this mechanism (European Commission 2017). This could eventually lead to the loss of EU voting rights for the country. Second, the aforementioned dispute and Council infringement proceedings over the compulsory relocation of the assigned number of refugees is in place for Hungary, the Czech Republic and Poland, supported by the European Court of Justice ruling from September 2017. This presents evidence that Visegrad states, apart from making occasional gestures towards each other that cost nothing, act and react individually. Slovakia, for example, is concerned in neither the first nor in the second issue.

The alternative to this situation is something that the Visegrad Four tried to prevent at the celebration of the $60^{\text {th }}$ anniversary of the European Union in Rome: differentiated integration. Closer co-operation of those willing to co-operate more closely sounded, in Visegrad parlance, like a cold shoulder of arrogant Western Europe against their marginalised Eastern relatives. Whether this was another act of self-victimization is a matter of opinion. A watered-down version with the wording that all members "will act together, at different paces and intensity where necessary [...] in line with the treaties" was eventually agreed upon by all EU partners in the Rome Declaration of March 2017 (European Union 2017). Further signs point to closer co-operation in a number of policy areas as envisaged and initiated by France and Germany. The door is open to all and treaty changes may happen eventually. Visegrad can and will reform in a number of policy areas, but refrain from others. All V4 countries will participate, for example, in the newly founded "Permanent Structured Cooperation" in defence and security issues. The alternatives for governments outside the mainstream are rather simple: either co-shape an agenda with like-minded partners or veto an initiative. The power of the veto-players is yet limited. A number of agreements that deal with the handling of the euro crises of the 2010 s indicate that in case disagreement overrides a reform process, member states can resort to bi- and multilateral agreements outside Union structures. Such arrangements will always play in the hands of those who conclude them. With that in mind, self-exclusion is something that governments in the region should seek to avoid. 


\section{References}

Ash, Timothy Garton (1993): In Europe's Name. Germany and the Divided Continent, London: Jonathan Cape.

Cabada, L. (2018): Visegrad Cooperation in the Context of Other Central European Cooperation Formats. Politics in Central Europe 14 (2). Doi: 10.2478/pce-2018-0014.

Council of the European Union (2015): Council Decision establishing provision measures in the area of international protection for the benefit of Italy and Greece. Interinstitutional File: 2015/0209 (NLE). Brussels: 22 September 2015. Available at: http://data.consilium.europa. eu/doc/document/ST-12098-2015-INIT/en/pdf (10 January 2018).

Court of Justice of the European Union (2017): Judgment in Joined Cases C-643/15 and C-647/15. Slovakia and Hungary $v$ Council. Luxembourg, 6 September 2017. Available at: http://curia. europa.eu/juris/documents.jsf?pro=\&lgrec=hu \& nat=or \& oqp=\&lg=\&dates=\&language=e n \& jur=C\%2CT\%2CF \& cit=none\%252CC\%252 CCJ\%252CR\%252C2008E\%252C\%252C\%252 C\%252C\%252C\%252C\%252C\%252C\%252C\%252Ctrue\%252Cfalse\%252Cfalse \& num=C-643 \%252F15 \& td=\%3 BALL \& pcs=Oor \& avg=\&page=1 \& mat=or \& jge=\&for=\&cid=140806 (10 January 2018).

Court of Justice of the European Union (2017): Press Release No 91/17. Judgment in Joined Cases C-643/15 and C-647/15. Slovakia and Hungary v Council. Luxembourg, 6 September 2017. Available at: https://curia.europa.eu/jcms/upload/docs/application/pdf/2017-09/cp170091en.pdf (10 January 2018).

Diez, Thomas (2004): Europe's Others and the Return to Geopolitics, Cambridge Review of International Affairs, 17 (2): 319-335.

Dostál, Vít (2017): Alleged Czech Discomfort. The Visegrad Group and the Cynic Reality, Visegrad Insight, 1 (10). Available at: http://visegradinsight.eu/alleged-czech-discomfort/ (10 January 2018).

European Commission (2017) Reasoned Proposal in accordance with Article 7(1) of the Treaty on European Union regarding the rule of law in Poland. Brussels: 20 December 2017. Available at: http://europa.eu/rapid/press-release_IP-17-5367_en.htm (10 January 2018) under bullet point "Reasoned Proposal under Article 7(1) for a Council Decision."

European Union (2017): The Rome Declaration. Declaration of the leaders of 27 member states and of the European Council, the European Parliament and the European Commission. Brussels: 25 March 2017. Available at: http://www.consilium.europa.eu/en/press/press-releases/2017/03/25-rome-declaration/ (10 January 2018).

Gallagher, Michael - Laver, Michael - Mair, Peter (2005): Representative Government in Modern Europe. Institutions, Parties, and Government, Boston: McGraw-Hill.

Hansen, Lene (2006): Security as Practice. Discourse Analysis and the Bosnian War, London and New York: Routledge.

Judt, Tony (2005): Postwar. A History of Europe since 1945, London: Penguin.

Kiss, László J. (2004): The Restatement of Hungarian Foreign Policy - from Kádárism to EU Membership. Foreign Policy Review 3 (1): 33-86. 
Kořan, Michal (2017) Central Europe: The Death of Dreams?, Think Visegrad Policy Brief (Brussels: Think Visegrad in Brussels). Available at: http://europeum.org/data/articles/ivf-koran. pdf (10 January 2018).

Kucharczyk, Jacek - Mesežnikov, Grigorij (eds) (2015): Diverging Voices, Converging Policies: The Visegrad States' Reactions to the Russia-Ukraine Conflict. Prague and Warsaw: Heinrich Böll Stiftung.

Tulmets, Elsa (2014): East Central European Foreign Policy Identity in Perspective, London and New York: Palgrave Macmillan.

Végh, Zsuzsánna (2017): Key Threats as seen in Visegrad, Visegrad Insight, 1 (10). Available at: http://visegradinsight.eu/narrowing-perceptions-meet-sustained-disunity/ (10 January 2018).

Visegrad Group (2017): Official Statements and Communiqués. Available at: http://www.visegradgroup.eu/documents/official-statements (10 January 2018).

Walsch, Christopher (2014): Visegrad Four in the European Union. An efficient regional cooperation scheme? International Issues \& Slovak Foreign Policy Affairs, XXXII (1-2): 25-41.

Walsch, Christopher (2015): Visegrad Four in Bosnia-Herzegovina. State-building and EU approximation from a Central European perspective, Society and Economy 37 (4): 427-441.

Wendt, Alexander (1999) Social Theory of International Politics, New York: Cambridge University Press.

Wittenberg, Jason (2015): Conceptualizing Historical Legacies, East European Politics \& Societies 29 (2): 366-378.

Christopher Walsch is a Visiting Professor of international relations and European studies at the Corvinus University in Budapest/Hungary. He worked also as the researcher at the Andrassy University Budapest/Hungary and in the Institute for Advanced Studies in Köszeg/Hungary. He studies modern history at the University of Vienna/Austria, $u$ international relations and European studies at the Central European University in Budapest/Hungary and development studies at the University of London/UK. He focuses on the Central European integration, regional cooperation within the EU and the Europeanization of the Western Balkans. He published several books to this topics and dozens of articles in German and English language, including Die EU-Strategie für den Donauraum auf dem Prüfstand (together with Ellen Bos and Christina Griessler, 2017), Od dunajské federace $k$ Visegrádu... a zpět? Staré a nové formáty středoevropské spolupráce [From the Danubian Federation towards the Visegrad... and back? Old and new formats of Central European cooperation] (with Ladislav Cabada, 2017), Der Traum vom Frieden - Utopie oder Realität? (together with Christina Griessler and Henriette Kovács, 2016).

E-mail: christopherwalsch@uni-corvinus.hu 